COSTUME

ISAAC: 'A WELL-DRESSED ACTRESS’

'A well-dressed actress': Exploring the Theatrical Wardrobe of Ellen Terry

\author{
By VERONICA ISAAC
}

A leading actress of the late nineteenth century, Dame Ellen Terry (1847-1928) exercised an unusual degree of control over her theatre costumes and played an active role in the design and creation of these garments. Drawing upon evidence gathered from a wide range of material culture sources, most notably her surviving costumes, this article considers the theatrical, historical, social and artistic context which shaped Terry's theatrical performances and stage dress. Terry's theatre costumes also reflected her personal views on dress, both on and off the stage. Particular attention will therefore be paid to the changes which occurred in Terry's stage dress as her increasing fame and financial independence enabled her to achieve greater control over the design and, importantly, the designers, of her theatre costumes. Through a close analysis of key pieces from Terry's stage wardrobe, this article will draw attention to the important part her theatre costumes played in a wider process of selffashioning in which Terry used her dress, both on and off the stage, to establish her status as an 'Icon of Aestheticism' and secure her enduring legacy as an actress who understood the 'art' of theatre.

KEYWORDS: Ellen Terry, nineteenth- and twentieth-century theatre, costume, aestheticism, self-fashioning 
INTRODUCTION

It is no use putting the right dress on the wrong actor or actress. The physical appearance of the person who is going to wear the dress must be borne in mind; so must the dramatic situation in which it is to be worn. Besides realizing the character of the period to which they belong, the dresses must be appropriate to the emotions of the play, and must have a beauty relative to each other as well as an individual excellence. ${ }^{1}$

DAME ELLEN TERRY (1847-1928) was one of the most popular and celebrated actresses of her generation. She achieved this status in spite of a professional career and personal life which directly challenged conventional Victorian morality and social codes: encompassing three marriages, two illegitimate children and at least two long-term love affairs. ${ }^{2}$ Whilst her career and life are by no means absent from theatrical record, the significant role that Terry's personal dress and theatre costume played in her selffashioning has been largely overlooked within recent scholarship. One of the few researchers to consider Terry’s dress has been Valerie Cumming. ${ }^{3}$ Building upon Cumming's important work, this article will establish Terry's close engagement in the design and creation of her theatre costumes and highlight the important part these garments played in a wider process of self-fashioning.

At the peak of her career Terry’s salary reached ' $£ 200$ a week' (the average weekly income of a leading lady was $£ 25$ to $£ 40$ ), and national and international tours had secured her fame throughout England, America and Australia. ${ }^{4}$ Whilst the status Terry achieved within her profession was not unique, the level of influence she was able to exercise over her stage dress and the immense sums invested in many of her most spectacular costumes was unusual. Terry's professional partnership with Sir Henry Irving (1838-1905), beginning in 1878 and lasting until 1902, played a significant part in enabling Terry to gain greater control over her stage dress. Terry's interest in costume design pre-dates their partnership, and was, as she herself acknowledged, fostered by her relationships with both the artist George Frederick Watts (1817-1904) and one of the foremost exponents of both Aestheticism and Aesthetic dress, the architect and designer Edward William Godwin (1833-1886). It was Irving, however, who raised Terry to the status of leading lady, and placed her in a position where she had the freedom to engage directly in the design and creation of her stage dress. As Terry reflected in 1908:

Neither when I began nor yet later in my career have I ever played under a management where infinite pains were not given to every detail. I think that far 
from hampering the acting, a beautiful and congruous background and harmonious costumes, representing accurately the spirit of the time in which the play is supposed to move, ought to help and inspire the actor. ${ }^{5}$

The importance Terry attached to 'harmonious costume' can be attributed in part to the influence of the Aesthetic movement. ${ }^{6}$ A dominant force within art and design from the late 1860s through to the early 1900s, this 'Cult of Beauty' promoted an 'art' which was 'self-consciously absorbed in itself, aware of the past but created for the present age, and existing only in order to be beautiful' ${ }^{7}$ It was a movement 'deeply concerned with the visual arts, valuing the frame as much as the picture' ${ }^{8}$ The values promoted by the Aesthetic movement, specifically the emphasis its adherents placed on the beauty that results through 'harmony', and the inspiration which can be drawn from the past, fuelled a wider desire for theatre costumes which were 'archaeologically correct and artistically appropriate'. ${ }^{9}$ Terry and her designers carried out painstaking research into past fashions when presenting historical productions. ${ }^{10}$ Similarly, she collaborated with the scene painters, consulting them 'about the colour, so that I should not look wrong in their scenes, nor their scenes wrong with my dresses' ${ }^{11}$

Whilst artistic factors were paramount, practical considerations also shaped Terry's approach to design. At five foot ten inches, Terry was unusually tall for a woman, particularly during the period in which she rose to fame. ${ }^{12}$ Self-conscious and awkward during her teenage years, Terry learnt to control her 'long and gaunt' limbs, achieving a reputation for graceful and gliding movement on the stage. ${ }^{13}$ When she first achieved success, and well into her mid-thirties, she remained extremely slim, describing herself as being 'thin to vanishing point'. ${ }^{14}$ Over the six decades spanned by her career, however, her figure became fuller. Recognizing that 'fat [was] fatal to ideality', and particularly inappropriate for a woman who was called upon to play young heroines well into her fifties, Terry learnt to adapt her dress to suit her changing figure. Noting that, by forty-eight, a 'waistband sloping downwards doesn't do for me at all', but a 'velvet band straight round \& the front soft stuff falling over [...] makes me look half the size'. ${ }^{15}$

This article will examine the practical and artistic influences which shaped Terry's attitude to costume design, and her own costuming practice. Specific attention will be paid to the importance of her early theatrical training, and to the figures within art and theatre who had a lasting impact on her approach to design and performance. It will also consider the significance of Terry's enduring commitment to the values 
associated with the Aesthetic movement, and the degree to which her stage garments express a desire to cement her status as an 'Icon of Aestheticism'. This discussion will feed into an examination of the role her theatre costumes played within a wider process of self-fashioning. It will provide the foundations for further investigations of the interrelationship between Terry's on- and off-stage dress and, as importantly, future research into the significance and variety of the 'clothing strategies' adopted by other performers. ${ }^{16}$

\section{A ‘CHILD OF THE STAGE’}

The daughter of two 'strolling players', Benjamin (1818-1896) and Sarah (1819-1892), Terry was immersed in the world of the theatre from her birth in $1847 .{ }^{17}$ She made her stage debut in 1856 at the Princess's Theatre, London. Aged eight, she performed the role of Mamillius in The Winter's Tale alongside the actor/manager Charles Kean (1811-1868) as Leontes. Kean's productions were distinguished by the importance he attached to 'historical authenticity'. ${ }^{18}$ An insight into Kean's attention to detail can be gleaned from Terry's recollections of the production. She remembered not only the 'little red-and-silver dress’ and 'very pink [and baggy] tights’ she wore as Mamillius, but also the pride inspired by her 'beautiful "property”'. This 'property’, ‘[...] a go-cart, which had been made in the theatre by Mr. Bradshaw', was '[...] an exact copy of a child's toy as depicted on a Greek vase’ (Figure 1). ${ }^{19}$

Terry spent three years, between the ages of eight and eleven, as part of the Kean's company. She appeared in Shakespearean productions, melodramas and pantomimes, leaving only when the Kean's management of the Princess Theatre ended in 1859. Her memoirs reveal the formative influence this apprenticeship had upon her attitude towards costume and design for the stage. Terry describes the succession of productions in which she appeared during this three-year period. ${ }^{20}$ As she relates, even when not performing she was studying the other members of the company and was frequently entranced by the set and costumes of her fellow performers. One of 'the most wearisome, yet essential details' of Terry's education was provided by the costume she wore for the role of Fairy Goldenstar in the Princess Theatre's 1857 Christmas Pantomime. ${ }^{21}$ This costume, 'as pink and gold as it was trailing', was her 'first long dress'. It was Mr Oscar Byrn (fl. 1856), at that time employed by the Keans as 'the dancing-master and director of crowds', who taught her how to manage her trailing skirts. Under his guidance Terry learnt to achieve the 'uprightness of carriage and 
certainty of step' essential to 'the art of deportment', and her graceful movement 'won high praise from Mr. Byrn’. Recognizing the long-term ‘value [of] all his [Byrn’s] drilling', Terry continued to attach great importance to being able to move gracefully and appropriately in her costumes throughout her career. ${ }^{22}$ Indeed, her principal costume designer at the Lyceum Theatre during the 1880s and 1890s, Alice ComynsCarr (1850-1927), regretfully observed that Terry, though possessing 'a fine sense' of historical dress, would 'jib at fashions that she fancied might interfere with her movement while acting' ${ }^{23}$

\section{A ‘SENSE OF DECORATIVE EFFECT’ 24}

After leaving the Kean's company, Terry spent several months acting alongside her sister Kate (1844-1924) as they toured the provinces. This was followed by a brief return to London, to work as an 'ingénue' at the Royalty Theatre, Soho, and subsequently for a year as part of a stock company in Bristol, between 1862 and $1863 .{ }^{25}$

Terry's career is then punctuated by what she described as a 'six year vacation'. Her initial departure from the stage aged sixteen in 1864 was prompted by her marriage to Watts. Though she returned to the stage for a brief period following the collapse of the marriage in 1865, she did so reluctantly. ${ }^{26}$ Her subsequent elopement with Godwin, in 1868, therefore offered her both a professional and personal escape.

Terry had first met Godwin whilst working in Bristol. The same committed attention to precise historical details for which Kean's productions were famous characterised Godwin's approach to design both on and off the stage, and the lasting influence both had on Terry is apparent. Indeed, Terry credited Godwin with initiating her ' $[\ldots]$ interest in colour, texture, effects of light on colour, the meaning of dress, and a certain taste for beauty which [she] never lost' ${ }^{27}$ In 1863, Godwin created a costume for her to wear as Titania in a production of A Midsummer Night's Dream. Though neither the costume nor any images of the dress survive, a sense of its appearance can be gained from Terry's descriptions of how they made the dress in Godwin's house in Bristol: 'He showed me how to damp it and "wring" it while it was wet, tying up the material as the Orientals do in their "tie and dry [sic]" process, so that when it was dry and untied, it was all crinkled and clinging'. Remembered by her as 'first lovely dress that [she] ever wore', this was a costume which, as Terry notes, she 'learned a great deal from'. ${ }^{28}$ 
Terry lived (unmarried) with Godwin for six years, raising their two children, Edith (b. 1869) and Edward (b. 1872). In 1874, however, financial necessity (bailiffs were calling at the house), and the offer of a leading role, compelled her to return to London and the stage. ${ }^{29}$ The success Terry achieved following her return to the stage in 1874 established her as one of the foremost actresses in London. ${ }^{30}$ In 1878 , this popularity brought her to the notice of actor/manager Sir Henry Irving. Having recently become the manager of the Lyceum Theatre, Irving offered Terry a position as the leading lady of the Lyceum Company. By this point in her career, Terry's education in art and design, if not complete, had at least reached a point at which she could accept Irving's offer, confident in her ability to bring the actor/manager 'help in pictorial matters'. As she declared, 'Judgement about colours, clothes and lighting must be trained. I had learned from Mr. Watts, from Mr. Godwin, and from other artists, until a sense of decorative effect had become second nature to me'. ${ }^{31}$

'GAUZE AND SPANGLES'

Whilst star performers, such as Terry, might be able to exercise a degree of control over their stage dress, or even to work with their own costumier to create these garments, most actresses, including those working at the Lyceum Theatre (where there was still an 'in-house' wardrobe), would have had costumes provided for them. ${ }^{32}$ This was the experience of the anonymous author of The Diary of An Actress or the Realities of Stage Life (1885), who moved from one company to another, and often had to wear the costumes required by her employers. ${ }^{33}$ Her diary records how, as a consequence, she was obliged to sacrifice her own artistic ideals of 'Shakespeare and black velvet', and think herself 'fortunate to go for a fairy queen in gauze and spangles'. ${ }^{34}$

One alternative for actresses with sufficient funds, particularly those in stock companies or travelling in pursuit of engagements, was to build up their own wardrobe of theatrical costumes. Indeed, they were frequently expected to provide their own garments for performances. ${ }^{35}$ Actresses new to the profession and working as 'women supers or supernumeraries' (assisting with group scenes, and seldom listed in the playbills), faired particularly badly and, as the actress and playwright Cecily Hamilton (1872-1952) recalled, '[...] if their dresses were not considered suitable the management looked at them askance'. ${ }^{36}$ In some instances, generous theatrical managers and performers might 'make the dresses a free gift to poorer performers'; in 
the majority of cases, however, actresses would have had to purchase their own garments. $^{37}$

One source of such garments was the flourishing trade in 'second-hand' costumes, and there were 'regular sales of second-hand and disused music-hall and pantomime costumes in London'. Prices varied according to the condition of the garments (many being heavily worn and repaired), but prices could still be extremely high, with a dress originally worth $£ 70$ fetching ' $£ 40$ ' if sold in a condition which is 'as good as new' ${ }^{38}$ These prices are for instance, as much, if not more, than might be charged for couture garments in the early twentieth century. ${ }^{39}$

An interview with Terry's principal costume maker at the Lyceum, Ada Nettleship (1856-1932), provides an insight into the huge sums invested in some of the actress's most spectacular costumes. Speaking in 1900, Nettleship revealed that 'many of Miss Terry’s dresses have cost $£ 100$ '. Indeed, over $£ 150$ was spent on one dress, 'twilled by [Nettleship's] girls entirely of gold thread' for the actress to wear as Guinevere in King Arthur (1895), with the same amount charged for the dress and amber necklace made for Terry as Imogen in Cymbeline (1896). ${ }^{40}$ In comparison, the $£ 47$ and $£ 49$ that Miss Marie Tempest (1864-1942) paid for costumes worn in The Greek Slave seem modest. As Nettleship noted, however, Miss Winifred Emery (18611924) paid $£ 300$ for the costumes created for her role in A Marriage of Convenience and Miss Brown Potter (1857-1936), who had 'all her clothes made in Paris', was widely accepted as the 'most extravagant stage dresser'. ${ }^{41}$

\section{NO WANTON EXTRAVAGANCE}

Though, by the late 1890s, she might pay up to $£ 150$ for a single costume, Terry continued to maintain that 'At the Lyceum wanton extravagance was unknown' and, as Cumming has observed, '[...] prided herself upon her ingenuity and, when necessary, her frugality'. ${ }^{42}$ Whilst Irving was clearly willing to invest heavily in his productions where required, funds were not limitless and Terry's memoirs highlight the ability of the companies' designers and makers employed to achieve stunning visual effects at minimal financial cost. ${ }^{43}$ As she remarked in 1911, '[... ] it is not always necessary to spend a great deal of money. I think I may say, without boasting, that I have always been well dressed on the stage, but I doubt if there has ever been a more cheaply dressed actress'. ${ }^{44}$ 
A surviving costume, worn by Terry as Ophelia in December 1878 for her first performance with the Lyceum Company, offers an example of her own efforts towards economy. ${ }^{45}$ As Terry's accounts of the production reveal, even at this early stage in their partnership, Irving allowed her a significant degree of control over the designs of her costumes. Confident that a black dress would express both Ophelia's character and situation in her final scene, Terry had already commissioned a costume made from 'crêpe de Chine and miniver' before her initial consultation with Irving. ${ }^{46}$ She was soon made aware, however, that 'there must be only one black figure in this play' and this was to be Irving's Hamlet. ${ }^{47}$ Horrified at 'having been the cause of needless expense', Terry ensured that her replacement 'Ophelia dress' was made from 'Bolton sheeting' (one of the cheapest types of cotton furnishing fabric), and was trimmed with 'rabbit fur', rather than the 'miniver' used for the previous costume (Figure 2). ${ }^{48}$

The use of rabbit fur to imitate ermine was a common theatrical device in this period, and surviving costumes worn by both Terry and Irving exemplify this practice. ${ }^{49}$ Scrap materials and costumes might also be recycled. For instance, as Walford Graham Robertson (1866-1946) explained, the 'rich' and 'glowing' costume Terry wore in Becket in 1893 was actually formed from ' $[\ldots]$ an old pink gown, worn with stage service', with 'the mysterious veiling' actually being 'the coarsest and cheapest black net'. ${ }^{50}$

‘OUR LADY OF THE LYCEUM’ (1878-1902) ${ }^{51}$

The success of Terry's stage partnership with Irving, which lasted over twenty years, stemmed from their mutual respect for each other's professional ability. Significantly, Irving appreciated Terry's knowledge of 'art and archaeology in dress', whilst she recognized that he often ' $[. .$.$] had a finer sense of what was right for the scene' { }^{52}$ Consequently, as Cumming discovered, although Irving ' $[\ldots]$ would decide upon the period in which the play was to be set and the tonal values of each scene', and the majority of the company's costumes would be made by the in-house wardrobe, Terry was able to create her costumes in collaboration with her own designers and dressmakers. ${ }^{53}$

Amongst the many figures involved in the creation of Terry's costumes over the course of her time in the Lyceum Company, and during the years immediately following her departure, three stand out. These are Patience Harris (1857-1901), Alice 
Comyns-Carr (who worked closely with the dressmaker, Ada Nettleship) and Terry's daughter, Edith Craig (1869-1947). The contrasting approach to stage dress favoured by each of these figures, together with Terry's own growing confidence in her own knowledge and understanding of costume design, is apparent in the resulting costumes. Patience Harris — 'Elaborate and pretentious' ${ }^{54}$

During the first decade of her career at the Lyceum Theatre, Terry's costumes were overseen by Patience Harris, the sister of Sir Augustus Glossop Harris (1852-1896), manager of the Drury Lane Theatre between 1879 and 1896, and daughter of actor and theatre manager Augustus Frederick Glossop Harris (1826-1873). Her mother had also been a theatrical costumier, founding the company Auguste et Cie in about 1873 . Following the same career path as her mother, Harris also worked with Auguste et Cie, forming part of the company until her death in $1901 .{ }^{55}$

From Terry’s appointment as leading lady in 1878, until c. 1886, Harris appears to have had a prominent role in designing Terry's costumes. Yet, limited information has survived regarding their professional relationship. Details can, however, be gathered from surviving costumes and photographs. Maker's labels preserved with costumes from Lyceum productions during this period, for instance, reveal that 'Auguste et Cie' also produced lavishly decorated costumes for Irving until the late 1880s. ${ }^{56}$ Similarly, stage photographs from the same period demonstrate Harris’s preference for elaborate and dramatic gowns. This approach contrasted with the 'simple designs’ Comyns-Carr would subsequently introduce to Terry’s stage wardrobe. ${ }^{57}$

The costumes Harris created for the 1882 production of Much Ado About Nothing provide a representative illustration of the more elaborate styles she favoured (Figure 3). Terry wore several different costumes during the production, but her dresses shared the same close-fitting bodices (stiffened with boning) and had full, trained skirts. The sleeves were particularly elaborate, and were generally full from the shoulder to the elbow, fitting closely from this point to finish in a tight cuff at the wrist.

Of the surviving costumes, two are virtually identical, being made from the same pale gold stamped velvet fabric and consisting of an open gown and underskirt, together with a separate stomacher. ${ }^{58}$ The front panel of the underskirts and the stomachers are decorated with a stylized, interconnecting pattern which is outlined with bugle beads. These two examples, and many of Terry's other costumes in this 
production, feature a distinctive, Elizabethan-inspired, upstanding collar. ${ }^{59}$ Formed from lace and supported on a wire frame, the visual impact of this collar is apparent both in the surviving garments and in the photographs. The use of a stiffened collar, rather than the starched ruffs also worn during this period, is likely to have been prompted by the desire to highlight Terry’s facial expressions, whilst ensuring that her movement was not unduly impeded by her clothing. Even so, Terry had clearly been persuaded by Harris to sacrifice some degree of comfort and freedom when wearing these heavy costumes, and her movement would still have been significantly restricted, not only by the weight of the silk velvet, but also the long trains, and close-fitting, boned bodices.

\section{Alice Comyns-Carr - 'Sinuous and flowing'}

During the decades which mark the peak of Terry's career, 'The Aesthetic movement' was a dominant force within British art and design. Terry owed her introduction to the artistic principles and leading advocates of Aestheticism to Godwin, but she maintained her allegiance to the movement after their relationship had ended. By 1879, Terry's status as a leading exponent of Aestheticism provoked Henry James (1843-1916) to declare that: "Miss Ellen Terry is "aesthetic"; not only her garments but her features themselves bear the stamp of the new enthusiasm'. ${ }^{60}$ Similarly, Walter Hamilton's survey of the movement (published in 1882) identified both Terry and Irving as actors whose 'intensity' earns them admiration from even 'the strict Aesthete', noting also that 'it is indeed at the Lyceum Theatre that Aestheticism in all its beauty can be seen' ${ }^{61}$

Terry was not simply following or being 'fashioned' by the movement, however. The 1887 production of The Amber Heart, in which Terry (appearing without Irving), played the lead, illustrates the degree to which she advertised and embraced her status as a leading figure in the Aesthetic movement. Securely established within the Lyceum Company, Terry chose this moment to dismiss her previous costume designer, Harris, in order to collaborate with Comyns-Carr. An advocate of Aestheticism both in her personal dress and professional work, Comyns-Carr had an innovative approach to design, which allowed the pair to create costumes which started, rather than followed, fashions. ${ }^{62}$

The costume Comyns-Carr created for Terry advertised her preference for Aesthetic dress and exemplifies the Aesthetic preference for garments which defied 
fashion and drew inspiration from the past to create styles that celebrated 'the natural form' and celebrated the 'individual' ${ }^{63}$ The wide, hanging sleeves reference depictions of medieval dress, whilst the loose, flowing swathes of pale silk echo classical robes, and are softly shaped using pleats and weights, rather than corsetry. The design also allowed Terry the freedom of movement that was considered so important within Aestheticism, and, as discussed, by Terry herself. The promotional photographs reinforce Terry's deliberate identification with Aestheticism, and show her positioned alongside a lily, which, like the sunflower, and Terry herself, had been adopted as a symbol by the Aesthetic movement (Figure 4). ${ }^{64}$

Terry was not the only actress to wear stage costumes influenced by the Aestheticism, but she was one of the pioneers of this form of stage costume. The American actress, Mary Anderson (1859-1940) was, like Terry, determined to abandon '[...] the velvet gowns, heels, wigs and stays commonly worn in classical roles'.65 Similarly, Lillie Langtry (1853-1929), who first rose to prominence when painted and idolized by leading figures within Aestheticism, began her stage career wearing costumes which deliberately referenced her status within the movement. ${ }^{66}$ Langtry soon abandoned 'classical draperies', however, in favour of costly couture gowns, and established a profitable partnership with the couturiers Charles Frederick Worth (18251895) and his son Jean-Philippe (1856-1926). ${ }^{67}$ Terry, in contrast, continued to work with Comyns-Carr, and returned to Aesthetic styles throughout her career.

In 1896, for instance, the artist Lawrence Alma-Tadema (1836-1912) was commissioned to design a costume for Terry's role as Imogen in Cymbeline. Describing it as '[...] one of the loveliest dresses that [she] ever wore', Terry's praise for this costume reflects the skill with which Tadema's design drew upon the myriad of styles associated with Aesthetic dress to create a costume suited to this specific actress. ${ }^{68}$ Whilst carefully referencing the draped and silhouette of classical robes, it has also been adapted to suit Terry's, by then, fuller figure. ${ }^{69}$ An examination of the costume, which survives at Smallhythe (the National Trust house in Kent formerly owned by Terry), revealed that the long-sleeved bodice is shaped with soft pleating and that Terry's waist was defined with loosely gathered triangular bands of twill silk (rather than a corset). The colours were also chosen with care. All fit within the colour palette of natural, muted, tones favoured within Aestheticism. ${ }^{70}$ The subtle cream and sea-green silk gauze used for the bodice flatter and highlight Terry's face and hands. However, conscious of 
the theatrical space for which the costume was intended, Tadema selected bolder tones for the skirt of the costume which is constructed from panels of purple, orange, russet and gold twill silk. The success of the costume, both as a work of art and a garment tailored to Terry as an individual, is apparent in surviving images of the actress (Figure 5).

Terry took an active interest in the design and creation of her theatrical costumes throughout her time at the Lyceum and was, as her friend, the couturier Lucile (Lady Duff Gordon, 1863-1935) declared, ‘intensely particular’ about her 'theatre clothes'. ${ }^{71}$ Appreciating the practical and artistic considerations which shaped the design process, she sought to achieve a balance between her individual taste in dress and the aesthetic demands of the stage, even, on occasion, sacrificing personal comfort for visual and dramatic effect. Her partnership with Comyns-Carr frequently allowed her to appear in the 'sinuous, flowing garments' she preferred but, as Cumming stresses, Terry ensured that such costumes were 'a natural extension of her art, not a superimposition upon it'. ${ }^{72}$ Indeed, as Terry affirmed, even though '[her] preference [was] for a loose, diaphanous dress' which she always felt 'happy in', when, playing Queen Katherine in Henry VIII (1892), she paid her '[...] tribute to archaeology in those awful stays, and added thick brocade dresses with fur sleeves of tremendous weight'. ${ }^{73}$

\section{Edith Craig - Colour and character}

As Terry's plans for the costumes she was to wear as Ophelia suggest, she was extremely conscious of the impact that colour could have on the stage, both for visual effect and as a signifier of mood and character. Terry's descriptions of her costumes also make apparent the degree to which colour influenced her approach to performance. When, in 1902, she was asked by a costume designer 'to play Mrs. Page, in “The Merry Wives of Windsor” in black panne velvet!', the actress protested that 'Rollicking, farcical comedy would be impossible in such a dress', and turned to her daughter, Edith Craig, for assistance. ${ }^{74}$ Craig had already proven her ability as a costumier, producing several garments for Lyceum productions, and, with Terry's help, had established her own premises at 13 Henrietta Street, Covent Garden, around $1900 .{ }^{75}$ Craig designed both garments and accessories for Terry to wear in The Merry Wives of Windsor and, as Terry stated, 'I know better than anyone how much the flame coloured dress I eventually wore helped me in Mrs. Page. Reds and yellows for comedy!'. ${ }^{76}$ At least one 
dress and three caps survive and provide a sense of the bold colours which are absent from the black and white photographs of Terry in the role (Figures 6 and 7). ${ }^{77}$

The success of Craig's efforts can be seen in Terry's subsequent observation that 'Edy has real genius for dresses for the stage'. As the actress explained, 'My dress for Mrs. Page was such a real thing — it helped me enormously — and I was never more grateful for my daughter's gift than when I played Mrs. Page'. ${ }^{78}$

Terry experienced comparable problems with the costumes suggested for the 1906 production of A Winter's Tale at His Majesty’s Theatre, complaining that,

For the trial scene in 'A Winter's Tale' the artist designed a dress of heavy purple cloth for Hermione, which, whatever it may have been as a dress, was quite unexpressive of the situation [...] How play the scene in a matronly, respectable, prosperous, amethyst coloured dress? Finally I wore draperies of white tableau-net, which I think well conveyed on the one side Hermione's physical weakness, on the other her stainless purity. ${ }^{79}$

The 'draperies of white tableau net' were again designed by Terry's daughter, and survive in the collection at Smallhythe. The dress, which had wide, hanging sleeves, with weights at the cuffs, is formed from overlapping layers of net. The surviving photographs of a fifty-nine-year-old Terry in the costume show that these layers of net fell in flattering soft folds across the body, running in wide bands from the shoulder to hem, where the dress extends into a point at the rear (Figure 8).

Terry had 'a very firm belief' in Craig's talents and her daughter's status as a woman who has '[...] shown again and again that she can design and make clothes for the stage that are both lovely and effective'. The actress employed her daughter to design many of the garments she wore after leaving the Lyceum, and in her autobiography Terry declared that, 'In all my most successful stage dresses lately she has had a hand, and if I had anything to do with a national theatre, I should, without prejudice, put her in charge of the wardrobe at once!' ${ }^{80}$

\section{'Sweet Nettle': Engagement in Design and Creation}

Although not credited in many of the surviving programmes, Terry's primary costume maker from 1887 onwards was Ada Nettleship. Described by Comyns-Carr merely as '[...] the wife of a well known animal painter, an old friend of mine, and an extremely clever dressmaker, who was anxious to find some means of adding to a slender income'; the origins and career of Nettleship have yet to be fully explored. ${ }^{81}$ It is known, however, that she had a particular specialism in embroidery, both designing her 
own patterns and training her staff to carry out such work under her supervision. ${ }^{82}$ An article published in the Boston Evening Transcript in 1893 sheds some light on her career. Originally '[...] distinguished as an art embroiderer in the style of William Morris' daughter', in response to the pleas of her clients, she expanded into dressmaking and has since established a reputation in publications such as Harper's Bazaar as 'perhaps the most unique dressmaker in the world' ${ }^{83}$

By the mid- to late 1890s Nettleship had clearly built a reputation for herself in London as a woman capable of producing both fashionable and theatrical attire. Terry's prominent place among Nettleship’s clientele is emphasized in much of the press coverage, with one reporter suggesting Nettleship that '[...] makes all Miss Terry’s official gowns and many of those which are unofficial'. ${ }^{84}$ This claim is substantiated by surviving correspondence between Terry and Nettleship in which the actress commissions Nettleship to make garments for her personal wardrobe as well as her stage attire. The success of their collaboration is evident in the praise lavished upon the creations 'which have now become the most beautiful and artistic dresses in the world — for what they are — picturesque stage representations’ ${ }^{85}$

The correspondence also provides an insight into the nature of their professional partnership. The letters frequently discuss suitable materials and colours not only for Terry's costumes, but also those of other performers. ${ }^{86}$ Terry is also very frank about her changing figure, and the need to adapt costumes accordingly. ${ }^{87}$ In one instance, Terry wrote to her 'Sweet Nettle' at 'one o'clock in the morning', asking her to 'run up a new dress for “Miss Gibson” for tonight's wear in The Corsican Brothers'. Terry enclosed a sample of the required material within her letter (now lost) to illustrate her point, explaining that the current dress was much 'too funereal' and that there was 'already white satin dress on the stage so that won't do'. ${ }^{88}$ Both the timing of the note and informality of the greeting indicate that Terry had implicit trust in Nettleship's ability to fulfil the commission and that this was not the first time that dressmaker had received such a last-minute demand.

\section{CONCLUSION}

This article has offered an insight into the costuming practice of an actress who exercised an unusual degree of control over her stage costumes and actively engaged in their design and creation. Although Terry's status within her profession was not unique, 
the level of influence she gained over her stage dress, and the immense sums invested in many of her most spectacular costumes, was unusual. It is recognized that she was an exceptional figure, with a rare degree of interest and engagement in the design and creation of her dress, both on and off the stage. Focusing on the stage dress of a specific actress has, however, made it possible to demonstrate the significant role that theatre costume can play in the 'clothing strategies’ performers from any era employ to establish, or resist, their 'public' and 'private' identities both on and off the stage.

This article has touched upon a small fraction of the garments which survive from Terry's theatrical wardrobe, and only gestured towards the parallels between her stage costume and personal dress. As this initial discussion has shown, great scope exists not only for further exploration of Terry's theatre costumes, but also those of her contemporaries and performers from other periods. The nature of Terry's partnership with Irving, together with her position as a celebrated and highly paid actress, placed her in an unusually privileged position. The fact that their relationship was founded upon a mutually beneficial compromise, rather than inequality or competition, meant that Terry’s artistic opinion, if not always accepted, was valued by Irving. Significantly, Terry's position as leading lady allowed her to achieve financial independence, and by the final years of their partnership she was contributing not only professional, but also financial support to the Lyceum Company. ${ }^{89}$ Terry's status within the Lyceum Company enabled her to collaborate with individuals whose approach to design reflected her own views on dress, and stage craft, in particular the visual harmony of the 'pictorial stage’ for which Lyceum Company productions had become renowned. ${ }^{90}$

Terry’s approach to design responded to, and was shaped by, the historic and artistic environment within which she lived and worked, specifically the greater importance being attached to the 'archaeology of dress' and the importance attached to 'beauty' and 'harmony' by members of the Aesthetic movement. She also acknowledged the lasting impact of the training she received from leading figures within the movement, Watts and Godwin in particular. It was Terry’s understanding of the 'art' of dress which enabled her to appreciate and exploit the power of dress to communicate her different 'identities', and which has made her such an interesting and valuable case study for this article. Whilst her decision to continue her allegiance to Aestheticism can be partially attributed to her early introduction to the movement, together with the style of production favoured by Irving and the Lyceum, there were 
also clear personal advantages for the actress. Terry was an individual who recognized the power of self-fashioning and whose professional career had made her acutely conscious of the important part that 'performance' both on, and off, the stage played in this process. Both her personal and theatrical dress played a significant role in her selffashioning and explicitly expressed and reinforced her prominent status within the Aesthetic movement. By presenting herself as an icon of a movement which venerated 'art', and 'the artist', Terry was able to establish herself as an 'artist' rather than simply an 'actress', and to secure her enduring status as an 'Icon of Aestheticism' and an actress who understood the 'art' of theatre design.

\section{Acknowledgements}

This article emerged from research supported by funding from Society of Theatre Research, the Southern Counties Costume Society and the Chedworth Society. I am also indebted to the staff at Smallhythe Place for facilitating my access to their collections and generously sharing their own knowledge and discoveries. Immense thanks are also due to my PhD supervisors, Professor Lou Taylor and Dr Kate Dorney, whose patient support and guidance made an invaluable contribution to the depth of my investigations.

\section{ENDNOTES}

\footnotetext{
${ }^{1}$ Ellen Terry, 'Stage Decoration', The Windsor Magazine (Copyright by S. S. McClure Company in the United State of America, 1911), pp. 71-90 (p. 87).

${ }^{2}$ Terry outlines some of these events in her own autobiography, published in 1908: Ellen Terry, The Story of My Life (London: Hutchinson, 1908). Amongst the biographies that followed, Nina Auerbach and Joy Melville provide the most reliable account her Terry's life and career. See Nina Auerbach, Ellen Terry: Player in Her Time (London: Dent \& Sons, 1987) and Joy Melville, Ellen and Edy: A Biography of Ellen Terry and her Daughter Edith Craig 1847-1947 (London: Pandora, 1987).

${ }^{3}$ See, for instance, Valerie Cumming, 'Ellen Terry: An Aesthetic Actress and her Costumes', Costume, 21 (1987), 67-74; 'Macbeth at the Lyceum', Costume, 12 (1978), 53-63; and 'First Knight: Henry Irving, 1838-1905', Costume, 40 (2006), 67-71.

${ }^{4}$ In fact, most West End actresses were fortunate to earn as much as $£ 10$ a week, and other performers working as ballet dancers or in productions touring 'the provinces' earned significantly less. Kerry Powell, Women and Victorian Theatre (Cambridge: Cambridge University Press, 1997), p. 7; Tracy C. Davis, Actresses as Working Women: Their Social Identity in Victorian Culture (London: Routledge, 1991), p. 26.

${ }^{5}$ Terry, The Story of My Life, p. 10.

${ }^{6}$ Terry was living with Godwin throughout the early phases of the Aesthetic movement (between 1868 and 1875).

${ }^{7}$ Stephen Calloway, 'The Search for a New Beauty', in Stephen Calloway, Lynn F. Orr, and Esmé Whittaker, The Cult of Beauty: The Aesthetic Movement, 1860-1900 (London: V\&A Publications, 2011), p. 11.
} 


\footnotetext{
${ }^{8}$ Lionel Lambourne, The Aesthetic Movement (London: Phaidon, 1996) p. 6.

${ }^{9}$ For a fuller exploration of the Aesthetic movement, see Elizabeth Prettejohn, Art for Art's Sake: Aestheticism in Victorian Painting (2007); Charlotte Gere, Aesthetic Circles, Design \& Decoration in the Aesthetic Movement (London: V\&A Publications, 2010); Calloway, Orr and Whittaker, The Cult of Beauty.

${ }^{10}$ Evidence of this research is preserved in the marginalia filling the books preserved in Terry's library at Smallhythe Place, and is also recorded in Terry's autobiography and the reminiscences of her costume designer Alice Comyns-Carr (Reminiscences (London: Hutchinson, 1926)).

${ }^{11}$ Terry, The Story of My Life, p. 69.

12 Terry's adult height was recorded on a passenger list for a journey she made to New York
} in 1907. n.a. 'Passenger list for the SS Philadelphia leaving Southampton Jan $12^{\text {th }} 1907$-arriving Port of New York Jan 19 ${ }^{\text {th }} 1907^{\prime}$ ', National Archives, Washington DC, Microform Serial T715, 1897-1957, Microfilm Roll 0821, line 1, p. 2.

${ }^{13}$ Terry, The Story of My Life, p. 37. Specific praise for Terry's graceful movement on the stage can be found in: n.a. 'Our Biographies: Being Brief Sketches of the Lives of Managers, Authors, Actors and Actresses No. XV. Ellen Terry', Press cutting, c. 1881, Ruth Canton Album: 'Chronicles of the Lyceum Theatre 1879-1883', Garrick Club, London, unpaginated.

${ }^{14}$ Terry, The Story of My Life, p. 129.

${ }^{15}$ Letter from Terry to Nettleship, V\&A Museum, ALS, THM/14/20/TERRY/5, the date of July 1895 has been subsequently added in pencil.

${ }^{16}$ This is the term employed by Kate Strasdin in 'Fashioning Alexandra: A Royal Approach to Style 1863-1910', Costume, 47.2 (2013), 180-97.

${ }^{17}$ Ellen Terry, The Story of My Life (London: Hutchinson, 1908), p. 5.

${ }^{18}$ This policy was, Hughes argues, enormously assisted by the queen's patronage. Alan Hughes, Henry Irving, Shakespearean (Cambridge: Cambridge University Press), p. 3.

${ }^{19}$ Terry, The Story of My Life, pp. 14-15.

${ }^{20}$ Terry, The Story of My Life, pp. 12-29.

${ }^{21}$ Terry, The Story of My Life, p. 20.

${ }^{22}$ Terry, The Story of My Life, pp. 20-21.

${ }^{23}$ Comyns-Carr, Reminiscences, pp. 215-6.

${ }^{24}$ Terry, The Story of My Life, p.150.

${ }^{25}$ Generally based in one venue, stock companies presented a different play each night. These were drawn from a repertory of productions and costumes and depended on a cast who could specialise in dramatic 'types'. Davis, Actresses as Working Women, pp. 6, 20-23.

${ }^{26}$ Terry, The Story of My Life, pp. 9, 61.

${ }^{27}$ Terry, 'Stage Decoration', p. 74.

${ }^{28}$ Terry, The Story of My Life, p. 47.

${ }^{29}$ Terry, The Story of My Life, pp. 82-83.

${ }^{30}$ Contemporary articles position Terry 'in the very front rank of our actresses', n.a. 'The Future of the Lyceum Theatre’, The Examiner, Issue 3686, 21 September 1878.

${ }^{31}$ Terry, The Story of My Life, p. 150.

${ }^{32}$ For further discussion of changing attitudes towards theatre costume during this period, see Joel H. Kaplan, and Sheila Stowell, Theatre and Fashion: Oscar Wilde to the Suffragettes (Cambridge: Cambridge University Press, 1994), pp. 3-4, 94-95; Christopher Breward, Fashioning London: Clothing and the Modern Metropolis (Oxford: Berg, 2004), pp. 87-91, and “"At Home” at the St. James’s: Dress, Decor and the Problem of Fashion in Edwardian Theater', The Edwardian Sense: Art, Design and Performance in Britain 1901-1910, ed. by Morna O'Neill and Michael Hatt (New Haven and London: Yale University Press, 2010), pp. 153-56.

${ }^{33}$ This diary has been examined in detail by Viv Gardner in 'The Three Nobodies: Autobiographical Strategies in the work of Alma Ellerslie, Kitty Marion and Ina Rozant', Auto/biography and Identity: Women, Theatre and Performance, ed. by Maggie B. Gale and Viv Gardner (Manchester: Manchester University Press, 2004), pp. 10-37. As she explains, the 
exact details of the diary's author are not known, but the British Library has attributed the work to Alma Ellersie.

${ }^{34}$ Alma Ellersie[?], Diary of an Actress or the Realities of Stage Life, ed. by H. C. Shuttleworth (London: Griffin, Farren \& Co., 1885), pp. 155, 159.

${ }^{35}$ Valerie Cumming, 'Theatrical Dress: Costume or Fashion?', in Understanding Fashion History (London: Batsford, 2004), p. 118; Diana de Marly, Costume on the Stage 1600-1940 (London: B. T. Batsford, 1982), p. 25.

${ }^{36}$ Cecily Hamilton, Life Errant (London: J. M. Dent, 1935), p. 44.

37 'Discarded Stage Costumes', Evening Post, LXVI, Issue 64 (12 September 1903), p. 10.

The Papers Past [n.d]. http://paperspast.natlib.govt.nz/

38 “Discarded Stage Costumes', Evening Post, LXVI, Issue 64 (12 September 1903), p. 10.

The Papers Past [n.d]. http://paperspast.natlib.govt.nz/

${ }^{39}$ See, for instance, discussions of the prices paid for such garments by Marion Sambourne (1851-1914), a member of the 'rising middle class', in Amy de la Haye, Lou Taylor and Eleanor Thompson, A Family of Fashion, The Messels: Six Generations of Dress (London: Philip Wilson Publishers, 2005), p. 37, and Heather Firbank (1888-1954), a member of fashionable London society, in Cassie Davies-Strodder, Jenny Lister and Lou Taylor, London Society Fashion 1905-1925: The Wardrobe of Heather Firbank (London: V\&A Publishing, 2015), pp. 39, 111, 142.

40 'What actresses pay for their dresses', New Zealand Herald, 25 August 1900. $<$ http://paperspast.natlib.govt.nz/cgi-in/paperspast?a $=\mathrm{d} \& \mathrm{~d}=\mathrm{NZH19000825.2.57.31}>$ [accessed 20 August 2014], p. 2.

${ }^{41}$ New Zealand Herald, 25 November 1900, p. 2.

${ }^{42}$ New Zealand Herald, 25 November 1900, p. 2. See also Terry, The Story of My Life, p. 171, and Valerie Cumming, 'Ellen Terry', pp. 72-73.

${ }^{43}$ Terry, The Story of My Life, pp. 170-71. This costume has been discussed in further detail by Cumming in 'Ellen Terry', p. 68.

${ }^{44}$ Ellen Terry, 'Some Ideas on Stage Decoration', McClures Magazine (January 1911), p. 293.

${ }^{45}$ This costume forms part of the Ellen Terry Collection at the actress's former home, Smallhythe Place. National Trust, ref. SMA.TC.168, 1118893.

${ }^{46}$ Terry, The Story of My Life, p. 157.

${ }^{47}$ Terry, The Story of My Life, p. 157.

${ }^{48}$ Terry, The Story of My Life, p. 157. Phyllis G. Tortora and Ingrid Johnson define Bolton sheeting as 'A coarse unbleached twilled English cotton fabric, sometimes dyed a cream colour, originally it was woven. $72 \mathrm{in}(80 \mathrm{cmm})$ wide. Uses: ground for crewel embroidery, also dresses, aprons, draperies'. Phyllis G. Tortora and Ingrid Johnson, The Fairchild Books Dictionary of Textiles (New York: Bloomsbury Publishing Inc., 2014), p. 66.

${ }^{49}$ The same effect was used for the archiepiscopal pallium worn by Irving in the title role of Becket (1893), now in the V\&A Museum, museum no. S.2752:2-2010. In a letter sent by Terry to Nettleship c. 1895, Terry she asks for a 'cheap cloak, looking like Ermine, but really innocent bunny rabbit’. Letter from Terry to Nettleship, V\&A Museum, ALS, THM/14/20/TERRY/5.

${ }^{50}$ Walford Graham Robertson, Time Was (London: Hamish Hamilton. 1931), p. 154.

${ }^{51}$ Robertson, Time Was, p. 149.

${ }^{52}$ Terry, The Story of My Life, p. 157.

${ }^{53}$ Cumming, 'Ellen Terry', p. 70.

${ }^{54}$ Comyns-Carr, Reminiscences, p. 79.

55 This company was founded by Maria Harris shortly after she was widowed in 1873. It remained in business until it was taken over by Nathans \& Co. (a costume house established in 1790 which remained a dominant company within film and theatre costume until $c$. 2000, when it was itself taken over by first Berman's and, subsequently, Morris Angel).

${ }^{56}$ These include a costume worn by Irving in an 1887 production of Lord Byron's Werner (V\&A Museum, museum no. S.2774-2010) and costumes worn by both performers for the 1882 production of Much Ado About Nothing (Irving as Benedick, V\&A Collections, museum no. 
S.2761:1- to 4-2010, and Ellen Terry as Beatrice, Ellen Terry Collection, Smallhythe, ref. SMA/COST/110 a,b,c [1118835]).

${ }^{57}$ Comyns-Carr, Reminiscence, p. 79.

${ }^{58}$ These two directly comparable costumes survive in two different collections. One is part of the Ellen Terry Collection, ref. SMA.COST.110 [1118835] and the other is held by the Museum of London, museum no. 65.90/4a-c. Further costumes associated with the Lyceum productions of Much Ado About Nothing survive in the Ellen Terry Collection; including ref. nos SMA.TC.149a\&b [1118874.1] and SMA.TC.157 [1118882]. Also with the collection at Smallhythe is a further costume from a revival of Much Ado About Nothing staged in 1903, (after Terry left the Lyceum Theatre), ref. SMA/TC/107 [1118832].

${ }^{59}$ See, for instance, 'The Ditchley Portrait of Elizabeth I', NPG 2561, National Portrait Gallery, London.

${ }^{60}$ Henry James, Nation, 13 June 1878 (J. H. Richards: New York).

${ }^{61}$ Walter Hamilton, The Aesthetic Movement in England (London: Reeves and Turner, 1882), pp. 31-32.

${ }^{62}$ Comyns-Carr's engagement with the Aesthetic movement has been explored in Loretta Clayton, 'Oscar Wilde, Aesthetic Dress and the Modern Woman: Or Why Sargent's Portrait of Ellen Terry Appeared in The Woman's World', Wilde Discoveries: Traditions, Histories, Archives, ed. by Joseph Bristow (Toronto: University of Toronto Press in association with the UCLA Center for Seventeenth- and Eighteenth-Century Studies and the William Andrews Clark Memorial Library, 2013), p. 148.

${ }^{63}$ These styles are discussed in more detail by Stella Mary Newton, Health, Art and Reason: Dress Reformers of the 19th Century (London: John Murray, 1974) and Kimberley Wahl, Dressed as in a Painting: Women and British Aestheticism in an Age of Reform (Durham, New Hampshire: University of New Hampshire Press, 2013).

${ }^{64}$ Oscar Wilde was amongst the figures credited with establishing the lily and sunflower as symbols of the movement. Charlotte Gere and Lesley Hoskins, The House Beautiful: Oscar Wilde and the Aesthetic Interior (London: Lund Humphries, 2000), pp. 12, 13, 26.

${ }^{65}$ Mary Anderson De Navarro, A Few Memories (New York: Harper and Brothers, 1896), pp. 117-19, 148.

${ }^{66}$ Langtry discusses her rise to prominence in her autobiography in Lillie Langtry, The Days I Knew (London: Hutchinson and Co., 1925), pp. 53-55 and 86-97. Laura Beatty also touches upon Langtry's connection with Aestheticism in her biography of Langtry, Lillie Langtry: Manners, Masks and Morals (London: Chatto and Windus, 1999), pp. 58-65. For further discussion of actresses who engaged with Aestheticism, see Clayton, 'Oscar Wilde, Aesthetic Dress', p. 151.

${ }^{67}$ Laura Beatty has discussed the profitable partnership Langtry established with the couturier Charles Worth, '[...] with whom she cleverly negotiated acknowledgement in her programme as part payment' for her costumes. Beatty, Lillie Langtry, p. 294.

${ }^{68}$ Terry, The Story of My Life, p. 350.

${ }^{69}$ Terry was forty-nine in the year Cymbeline was staged and, as Comyns-Carr reveals in her Reminiscences, there was some debate between Tadema and Terry about how to achieve a costume which would be 'becoming to her figure'. Comyns-Carr, Reminiscences, p. 254.

${ }^{70}$ Numerous articles and handbooks on Aesthetic dress address the Aesthetic preference for colours achievable with natural, rather than the new chemical dyes. See, for examples, Mrs H. R. Haweis, The Art of Beauty (London: Chatto and Windus, 1878), pp. 175-204, and Louise Higgin, Art As Applied to Dress: With Special Reference to Harmonious Colouring (London: J. S. Virtue, 1885).

${ }^{71}$ Lady Duff Gordon, Discretions and Indiscretions (London: Jarrolds, 1932), pp. 33-34.

${ }^{72}$ Cumming, 'Ellen Terry', p. 73.

${ }^{73}$ Terry, 'Stage Decoration', p. 88.

${ }^{74}$ Terry was still working at the Lyceum Company at this point, and had obtained Irving's permission to appear in the production at His Majesty's Theatre. She discusses this arrangement in her autobiography. Terry, The Story of My Life, p. 323. 


\footnotetext{
${ }^{75}$ Katharine Cockin has also written extensively about Craig and her work with the theatre, see particularly Katharine Cockin, Edith Craig (1869-1947): Dramatic Lives (London: Cassell, 1998), pp. 40-42.

${ }^{76}$ Terry, ‘Stage Decoration’, p. 89.

${ }^{77}$ One of the three surviving caps is in the Museum of London collection, museum no. 53.94/1 and 2. The dress and the other two caps are in the Ellen Terry Collection, Smallhythe, ref. SMA.TC.113a-c, 1118838.1-3 and SMA.TC.233, 1118958.

${ }^{78}$ Terry, The Story of My Life, p. 323.

${ }^{79}$ Terry, 'Some Ideas on Stage Decoration', p. 293.

${ }^{80}$ Terry, The Story of My Life, pp. 84-85.

${ }^{81}$ Comyns-Carr, Reminiscences, p. 80. Mrs Ada Nettleship was married to the artist John
}

Trivett Nettleship, particularly known for his paintings of animals. His work was exhibited at the Grosvenor Gallery in 1883, the New Gallery in 1891 and at the Winter Exhibition of the Watercolour Society in 1894.

${ }^{82}$ The Queenslander, 3 April 1897, p. 747.

${ }^{83}$ Boston Evening Transcript, 16 January 1897, p. 16.

${ }^{84}$ Boston Evening Transcript, 16 January 1897, p. 16.

${ }^{85}$ Boston Evening Transcript, 16 January 1897, p. 16.

${ }^{86}$ Terry, letter to Nettleship, dated added by hand in pencil, 10 November 1892. V\&A Museum, ALS, THM/14/20/TERRY/5.

${ }^{87}$ An example of Terry's requests for these modifications to costumes can be found in THM/14/20/TERRY/5, Letter to Ada Nettleship, dated in pencil July 1895. ALS, V\&A Museum, London.

${ }^{88}$ Terry, Letter to Nettleship, c. 1895. V\&A Museum, ALS, THM/14/20/TERRY/5.

${ }^{89}$ In a letter from sent from Terry to her costumier. Nettleship on 3 June 1901, Terry explains that as the Lyceum Company cannot no longer afford to pay for new dresses she will 'pay the bill' herself. See THM/14/20/TERRY/7, Letter to Ada Nettleship, dated 3 June 1901. Autographed Letter Series, V\&A Museum.

${ }^{90}$ Martin Meisel, 'Irving and the Artists', Realizations: Narrative, Pictorial, and Theatrical Arts in Nineteenth-Century England (Princeton: Princeton University Press, 1983), pp. 402-32.

\section{NOTE ON CONTRIBUTOR}

\section{Dr. Veronica Isaac}

Veronica Isaac is a dress historian, with a particular specialism in the dress and theatre costume of the nineteenth and early twentieth century. She currently works as a museum curator and lecturer and recently completed a $\mathrm{PhD}$ thesis investigating the personal and theatrical dress of the actress Ellen Terry (1847-1928). Her doctoral research was carried out at the University of Brighton, and in collaboration with the Department of Theatre and Performance, Victoria \& Albert Museum, and the National Trust property, Smallhythe Place, (Terry’s former home). 
FIGURE 1. Unknown photographer, Charles Kean as Leontes and Ellen Terry as Mamillius in The Winter's Tale, Princess's Theatre, 1856. Sepia photograph on paper, $19.4 \times 14.5$ cm. London: V\&A Museum, Guy Little Collection, S.133:146-2007 (C) V\&A Museum, London

FIGURE 2. Window \& Grove, Ellen Terry as Ophelia in Hamlet, Lyceum Theatre, 1878. Sepia print of photograph on paper, $26.5 \times 17.6 \mathrm{~cm}$. London: V\&A Museum, Harry Beard Collection, S.6044-2009

(C) V\&A Museum, London

Figure 3. Window \& Grove, Ellen Terry as Beatrice in Much Ado About Nothing, Lyceum Theatre, 1882. Sepia photograph on paper, $14.5 \times 10.6 \mathrm{~cm}$. London: V\&A Museum, S.133:369-2007

(C) V\&A Museum, London

FigurE 4. Window \& Grove, Ellen Terry as Ellaline in The Amber Heart, Lyceum Theatre, 1887. Sepia photograph on paper, $14.4 \times 10.5 \mathrm{~cm}$. London: V\&A Museum, S.133:407-2007

(C) V\&A Museum, London

FIGURE 5. Unknown photographer, Ellen Terry as Imogen in Cymbeline, Lyceum Theatre, 1896. Hand-tinted photograph. Smallhythe Place, Kent: Ellen Terry Collection, National Trust, Inv. no. 1119387

(C) National Trust Images / John Hammond

Figure 6. Window \& Grove, Ellen Terry as Mistress Page in The Merry Wives of Windsor, His Majesty’s Theatre, 1906. Platinum print, $13.6 \times 9.9 \mathrm{~cm}$. London: National Portrait Gallery, NPG Ax131327

(C) National Portrait Gallery, London 
Figure 7. Tunic, part of a costume worn by Ellen Terry as Mistress Page in The Merry Wives of Windsor, His Majesty’s Theatre, 1903. Smallhythe Place, Kent: Ellen Terry Collection, National Trust, Inv. no. SMA.TC.113a [1118838.1]

(C) Veronica Isaac, 26 July 2015

FiguRE 8. Window \& Grove, Ellen Terry as Hermione in The Winter's Tale, His Majesty's Theatre, 1906. Sepia photograph on paper, $14.1 \times 10.1 \mathrm{~cm}$. London: V\&A Museum, S.133:514-2007

(C) V\&A Museum, London 